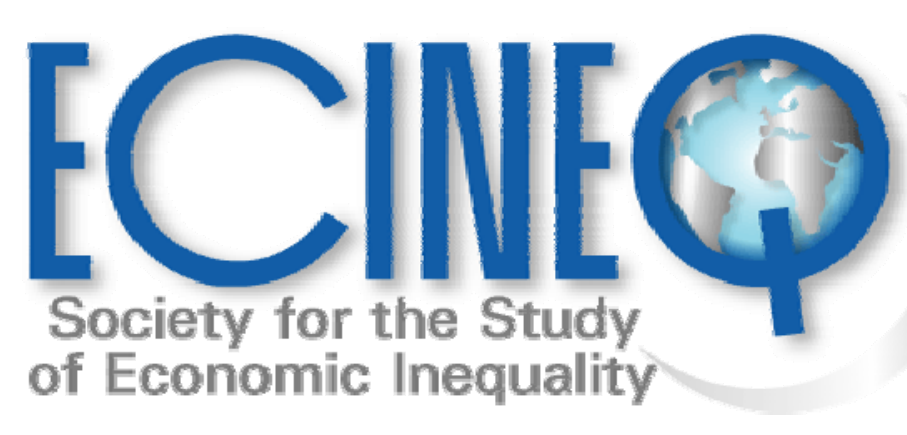

Working Paper Series

\title{
When Can the Rabble Redistribute? Democratization and Income Distribution in Low- and Middle-income Countries
}

Philip Nel 


\title{
When Can the Rabble Redistribute? Democratization and Income Distribution in Low- and Middle-income Countries
}

\author{
Philip Nel ${ }^{1}$ \\ D epartment of Political Studies, U niversity of 0 tago
}

\begin{abstract}
In contrast to the experience in high-income OECD countries, the introduction of democracy in most low- and middle-income countries (LMICs) has been followed, as a rule, by a concentration of income. Using the median voter hypothesis as analytical tool, this paper explores the conditions under which positive regime change can lead to the mitigation of income inequality in LMICs. Analysis of panel data over the period 1960 to 1999 supports the contention that the degree to which popular sovereignty had been institutionalised through regime change is an important condition. Contrary to mainstream theory, economic openness in general tends to increase and not mitigate income inequality in countries where skilled labour is in short supply. Only in those countries with the requisite state capacity to disseminate skills amongst their populace on a broad scale, the electorate can use the vote effectively to reduce the effects of this tendency.
\end{abstract}

Keywords: Income distribution; redistribution; democratisation; median voter hypothesis

JEL classification: C33, D 31, F59, H53

\footnotetext{
${ }^{1}$ Contact details: philip.nel@ stonebow.otago.ac.nz. D epartment of Political Studies, University of O tago, D unedin 9000, New Zealand
} 
1. Introduction

The last decades of the $20^{\text {th }}$ century experienced an extensive introduction and/or deepening of electoral democracy in low-and middle-income countries (LMICs); a series of events that Diamond calls 'a democratic breakthrough without precedent in world history' (Diamond, 1999: 24). ${ }^{2}$ However, contrary to the optimistic expectation of many analysts and decision makers in Western democracies that all good things go together, the available evidence suggests that episodes of positive regime change in LMICs as a rule have seldom been followed by a reduction of wealth and income inequality in those countries. The purpose of this chapter is to propose an explanation for this anomaly.

Why should be concerned at all about the relationship between economic (income and wealth) inequality and democracy in low- and middle-income countries? Two sets of reasons have emerged in the recent literature. Firstly, it is important to consider the effects that political institutions could have on reducing levels of economic inequality, given the emerging consensus that high levels of initial economic inequality have negative consequences for the overall development prospects of LMICs. In contrast to an earlier belief that there is an inescapable trade-off between growth and inequality in modernising societies (Kuznets 1955; 1963), a large number of studies in the 1990 s and early 2000 s postulated that economic growth and pro-poor development

\footnotetext{
${ }^{2}$ See Doorenspleet (2000) for an analysis of this phase of global democratization.
} 
is retarded when income and asset inequality exceeds a certain threshold (Aghion \& Garcia-Penalosa, 1999; World Bank, 2001; 2005; Cornia, 2004; Chen \& Ravallion 2000; Gugerty \& Timmer, 1999; Naschold, 2002; Birdsall, 2001; Birdsall \& Londono, 1997; Nel, 2003). Easterly (2002) shows that inequality, independently of other factors, is a large and statistically significant barrier to developing the institutional framework and human capital on which successful development depends. A recent study on inequality in Latin America concludes that inequality hinders the implementation of sensible macroeconomic strategies, retards demand, impedes the development of propoor trade policies, limits the growth of human capital stocks, raises social discontent, and limits the degree of political participation (Justino, Litchfield \& Whitehead, 2003:64-65). There is also evidence that inequality can hamper poverty relief. The 2000/2001 World Development Report (World Bank 2001: 35) comments:

'while economic growth is systematically associated with poverty reduction, the rate at which growth translates into lower poverty depends on the initial level of inequality in the distribution of income and how that distribution changes over time.'

Dagdeviren et al. (2001) confirm this conclusion. They find that for a large sample of developing countries a strategy of marginal redistribution of wealth from the rich to the poor, or a strategy of equal distribution of growth benefits, are more effective in reducing poverty than increases in economic growth that are distributionally neutral.

Secondly, it has been suggested that the failure of emerging democratic regimes to spread wealth and income more equitably can undermine the trust of the populace in political institutions, can exacerbate civil strife, and so at best can retard the consolidation of democratic advances, or at worst precipitate a slide back into 
authoritarianism. ${ }^{3}$ Economic inequality and democracy are thus jointly determined, and much seems to be at stake in our attempt to find out why political institutions in recently democratised societies have such a poor track record when it comes to the mitigation of economic inequality.

The chapter proceeds by first defining the core concepts used and by reviewing the available evidence concerning the effect of democracy and democratization on inequality. In a following section, an attempt is made to develop an explanation for the empirical patterns reviewed. A final section draws some implications for our understanding of the determinants and effects of economic inequality, and for policy debates about the focus and nature of political reform in LMICs.

As is common in inequality studies, this chapter focuses on income inequality as an appropriate approximation of economic inequality in general (Champernowne \& Cowell, 1998), based on the assumption that there is a significant correlation between income and wealth distribution, and between the distribution of both these social goods and the economic opportunity profile of the typical LMIC. This study forms part of the literature that explores how political factors shape income inequality, and we look in particular at the effect of democratisation, which is defined as the process through which a political regime graduates to democracy (see below). Our time focus is prescribed by the availability of high quality income inequality data, and we can therefore look only at the last four decades of the previous century. During this time, it was mostly LMICs that experienced democratic transitions, that is, countries that by the

\footnotetext{
${ }^{3}$ In their comprehensive study of democracy and economic development, Przeworski et al. find that 'democracies are less stable in societies that are more unequal to begin with, in societies in which household income inequality increases, and in societies in which labor receives a lower share of value added in manufacturing.' (2000: 122).
} 
end of the 1990 s had a capita income up to US\$10,065. ${ }^{4}$ Their number were join by a small group of high-income countries, such as Taiwan and South Korea, who also made the succesful transition from autocracy to democracy. LMICs consist of two distinct groups, namely ex-communist transition economies and what are generally referred to as developing countries. This chapter wants in particular to explain why it is that the latter group has found it so difficult to translate political equality into economic equity, and most of the discussion therefore centres on developing LMICs. Part of the analysis is based on a cross-sectional time-series empirical analysis, and in order to ensure balance and the broadest possible spectrum of variation a large sample of 108 countries, of which twenty-six are high-income and eighty-two LMICs, has been constructed from the income inequality dataset that we use as our primary data source (see below).

\section{Concepts and Evidence}

A political regime is the set of norms, rules, and practises that determine the distribution of political rights between actors in a polity, how these rights can be exercised, and what this means for the exercise of control over institutions of power such as the state (Sanders, 1981: 51-63; Przeworski et al., 2000:18). In a democracy the expectation is that those who find themselves in lower socio-economic positions will use the opportunities provided by political equality to reduce their disadvantage. In contrast, we have come to expect that in autocracies socio-economic inequalities will be mirrored in the concentration of political power in the hands of the few. Autocracies systematically exclude some sections of society from political rights in an attempt to prolong the exclusive control of one group or individual over the state. The crucial regime

\footnotetext{
${ }^{4}$ Calculated by the World Bank using the exchange rate of the local currency against 1994 USDollars (Atlas method).
} 
difference between autocracies and democracies is that the latter are characterised by popular sovereignty while in the former sovereignty resides in the hands of the few. In the useful terms suggested by Lane and Ersson (2003:2) democracy is 'a political regime where the will of the people ex ante becomes the law of the country... ex post.' As Rueshemeyer, Stephens \& Stephens comment, 'democracy, then, is a rather counterintuitive state of affairs, one in which the disadvantaged many have, as citizens, a real voice in the collective decision making of politics' (1992: 41).

There are, of course, more than one variant of democracy and a number of distinguishing features have been emphasised in the literature. The crucial distinction, for our purposes, is between democracies that have institutionalised popular sovereignty and those in which regular competitive elections do take place, but where political veto power remains concentrated in the hands of a self-perpetuating elite within whose ranks leadership election is monopolised. Marshall and Jaggers (2002) conceive of democracy as consisting of three essential interrelated elements. The first is the presence of institutions of competitive elections in which the electorate can express effective preferences about competitively selected candidates and alternative policies. The second is the existence of effective institutionalised constraints on the exercise of power by the executive and, thirdly, the guaranteeing of civil liberties to all citizens. These three institutional characteristics combine to guarantee popular sovereignty, that is the legally entrenched right of the citizenry to exercise a veto over public officials and policies without fearing reprisal. This implies that privileged political positions for extraparliamentary interest groups such the military, for example, are done away with and that constitutionalism and the rule of law have been institutionalised as means to secure horizontal constraints on the power of officials/leaders (Diamond, 1999: 10-11). Keeping these requirements in mind it is possible to distinguish between 'full', 
alternatively 'mature' or 'institutionalised' democracies on the one hand, and 'partial', 'incomplete', 'failing', 'pseudo', or 'defective' democracies on the other. ${ }^{5}$ Among these terms 'partial democracy' is perhaps the less pejorative, and in what follows we will distinguish between three regime types: Firstly, autocracies which refers to regimes in which elections are not based on universal franchise, or more commonly today, in which elections are not competitive in the sense that the electorate is not confronted with a real choice or in which choices cannot be exercised in freedom. Secondly, partial democracies in which there are competitive universal-franchise elections, but popular sovereignty may be impeded by the undue influence of forces not under popular control (such as the military, for instance), some restrictions on the rule of law and on civic and political freedoms may apply, and in which the means for the electorate to exercise effective control over public officials may not be fully developed. Thirdly, democracy in which civil and political liberties are respected, there is effective control over the exercise of power by the executive, and in which competitive elections are held regularly. Once these three requirements are met, we can speak of popular sovereignty having been institutionalised. ${ }^{6}$

The combined regime measure developed in the POLITY IV dataset (Marshall \& Jaggers, $2000 ; 2002)^{7}$ provides us with the means to operationalise the distinctions between these three regime types. Autocracies fall short on all three characteristics, but to varying degrees: they restrict or suppress civil liberties and political participation;

\footnotetext{
${ }^{5}$ See Epstein et al. (2003); Reich (2002); Lee (2005).

${ }^{6}$ This conception allows for a one-party dominated regime to be recognised as an institutionalised democracy as long as the three Marshall \& Jaggers criteria are met. This is a less stringent requirement than that proposed by Przeworski et al. (2000), who define democracies as regimes in which parties lose elections. This may set the bar unrealistically high for many LMICs, though, viz. the cases of Botswana and South Africa, for instance.

${ }^{7}$ I use the Polity 2 measure (revised combined polity score) which is geared towards the use of the POLITY regime measure in time-series analyses. It modifies the combined annual Polity score by applying a set of simple coding rules to deal with transitional periods and other exceptional circumstances (see Marshall \& Jaggers, 2002: 8).
} 
executive selection usually takes place within a power elite; and there are few institutional constraints on the exercise of executive power. To capture the variety of autocracies, Marshall and Jaggers use an eleven-point scale from -10 to 0. Similarly, they scale democratic regimes from +1 to +10 , the latter score being an indicator of a full/institutionalised democracy. A regime that scores between +1 and +6 inclusive is here categorised as a partial democracy, because they fall significantly short on one of the three requirements. Those with a score of +7 to +10 are here regarded as democracies, because they meet well with all three requirements, but not necessarily comprehensively in respect of all three. ${ }^{8}$ An episode of 'democratization' occurs whenever there is a positive regime transition from either autocracy or partial democracy to democracy.

The relationship between inequality and democracy in high, middle, and low income countries has received considerable attention, ${ }^{9}$ with most studies concluding that democracy reduces inequality. ${ }^{10}$ Muller (1988) finds that if we use a measure that combines depth and longevity of democracy, there is indeed a significant negative effect on inequality: durable democracies are less unequal. Burkhart (1997) uses only a depth measure of democracy but he also tests for the presence of a second-order polynomial relationship. He finds that (level of) democracy and inequality are indeed nonlinearly related: partial democracies do not succeed in reducing inequality, but at about the

\footnotetext{
${ }^{8}$ It is of course problematic to use what was intended as a continuous scale of democracy to arrive at a categorical distinction between types of democracy. Nevertheless, the POLITY IV dataset has so many advantages in terms of clarity of conceptualisation and operationalisation that researchers interested in the categorisation of types of democracy prefer to use it instead of less transparent categorisations such as Reich (2002). The important question is where exactly to draw the line on this continuous scale between democracy and partial democracy, and the opinions differ on this (see Lee, 2005; and Epstein et al. 2003). The cut-off used here, namely the score of seven, is deemed to be sufficiently stringent in terms of the three democracy criteria discussed above.

${ }^{9}$ See Bollen \& Jackman (1985) for a discussion of the early literature. See also Muller (1988), Simpson (1990), Burkhart (1997), Przeworski et al. (2000), Gradstein et al. (2001) and Lane \&Ersson (2003).

${ }^{10}$ One important exception is Bollen \& Jackman (1995), who find no evidence of a direct relationship of depth of democracy on inequality, and argue that it is level of economic development that determines both. However, most recent work point out some problems with the Bollen and Jackman specification.
} 
midpoint of his scale measuring the depth of democracy, the effect is reversed. Earlier, Simpson (1990) also suggested an inverse, U-shaped relationship between the level to which political and civil rights are respected in a country and domestic inequality. Lee (2005) concludes that 'deeper' democracy is more inclined to reduce inequality, once we control for the size of the public sector, than do partial democracies.

There are a couple of problems with this literature, though. Firstly, the quality of the income inequality data used in most of the extant studies can be questioned. It is notoriously difficult to get good quality income data for a large cross-section of developing LMICs, and none of the existing studies manages to solve the data quality problem in any consistent and persuasive manner. Secondly, as these studies use 'static' indicators of the independent variable (= the level of democracy) they do not explicitly ask how the time-variant dynamic of democratization, in contrast to the static of regime status, affects income distribution. ${ }^{11}$

The empirical strategy suggested here to overcome these two problems is, first, to use a high-quality cross-sectional time-series (panel) dataset, analysed by means of estimation models that can pick up not only the effect of the quality of democracy, but also how the dynamic of a transition to democracy affects subsequent income distribution relative to the dynamics in other countries. The income inequality panel data used here comes from the Estimated Household Income Inequality (EHII) dataset compiled by the University of Texas Inequality Project, under the leadership of James

\footnotetext{
${ }^{11}$ The one exception is the quasi-experimental study by Chan (1997) which looks at the effect of democratization in Taiwan, South Korea, and Singapore on public policies that have redistributive effects. His results for Taiwan and South Korea indicate that public spending on education and social security did increase after the introduction of democracy. However, apart from being limited to three case studies, Chan's study also has two other shortcomings: first, it focuses on public expenditure per se and not on the distributive effects that public spending has on various income groups. Second, his study is not based on an explicit theory that sets out the causal mechanism through which democratization can lead to redistribution.
} 
Galbraith. This is the most comprehensive within-country income inequality dataset available and is especially attractive because it is based on a quality source that remains consistent over time, namely the UNIDO dataset on manufacturing pay or wage inequality. In contrast, alternative comprehensive inequality datasets, such as the widely used Deininger and Squire World Bank inequality dataset (Deininger \& Squire, 1996; 1998) includes data that derive from different types of household survey sources and that have been collected using widely divergent methodologies across countries and across different time periods within countries. Clearly, this poses insurmountable problems for both cross-country and within-country time-series research, as Knowles (2005) points out. In addition, the coverage of the Deininger \& Squire dataset of developing countries is fairly limited. The EHII dataset is produced by combining information from the UNIDO dataset with high-quality information from other household income inequality datasets, as well as other relevant information such as the ratio of manufacturing employment to total population, the degree to which a country's population has become urbanised, and population growth. This information is then combined in a regression that produces a pooled time-series of estimated household income inequality (Galbraith \& Kum, 2005). ${ }^{12}$ We average the data over five-year periods, which produces a balanced pooled time-series of 551 observations covering 108 countries and spanning eight semi-decades, starting from 1960-64 and ending with the semi-decade 1995-99.

The second part of the empirical strategy used here is to employ a fixed-effects estimation model to test for the dynamic effect of democratization on subsequent income inequality. Fixed effects models have the two advantages of controlling for omitted variables that differ between countries but are constant over time, and of

\footnotetext{
${ }^{12}$ Because it is based primarily on pay/wage data, this dataset is applicable only to analyses focusing on pre-tax and pre-transfer (= gross) income.
} 
allowing us to use changes over time in the included variables to estimate the effects of independents on the dependent. Our independent variable is a dummy (DEMDUM) which distinguishes between polities with a Polity2 score of more than 7 (dummy value $=1$ ), and polities with a score of 6 and less (dummy value $=0$ ) at any particular time. A lagged fixed-effects model picks up what the effect of changes in a country's DEMDUM status in one period is on the inequality level in that country in a subsequent period. As mentioned above, the literature suggests that there is an inverted $U$ curve relationship between level of democracy and inequality, and we are hence justified in expecting that the transition to deeper, more institutionalised democracy will be associated with the lowering of income inequality levels in subsequent periods, as poorer citizens use the vote to shift state spending in favour of their income opportunities (we will unpack this hypothesis in more detail in the next section). 
Table 1: Estimations of net effect of democratization on income inequality

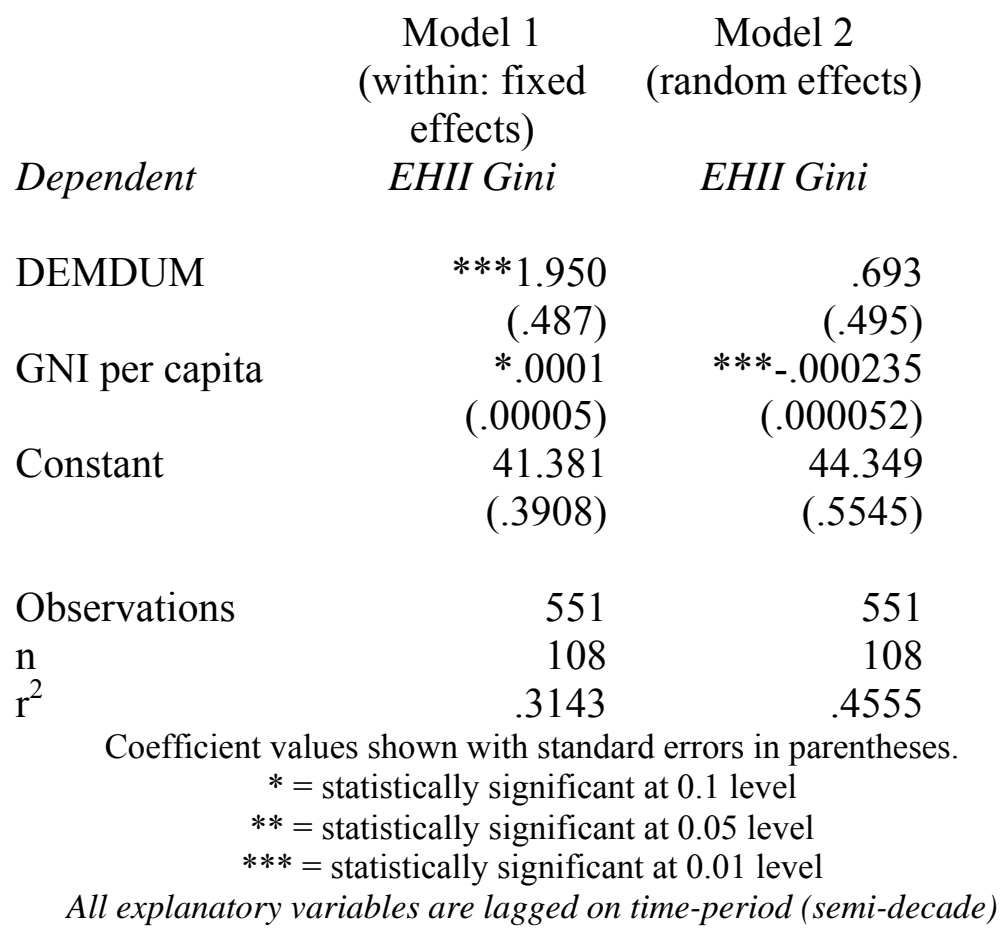

Model 1 in Table 1 reveals that the effect of democratization in our full sample of 108 countries is to increase inequality, net of the effects of within-country variation in a vector of control variables captured by the lagged purchasing-power-parity value of Gross National Income per capita (GNIpc). Model 1 is the fixed effects (within) estimation, and shows that a positive regime change in one time-period from autocracy to democracy, or from partial democracy to democracy, is systematically and significantly associated with higher levels of inequality in subsequent periods. This confirms the results of an earlier study that looked at the effects of democratization on the income shares of the poor, the middle class, and the rich in thirty-six LMICs over an intense period of the spread of democracy, namely 1985-1995 (Nel, 2005). This earlier study used comparable household survey data and found that the income share of the poor (lowest $40 \%$ ) and the middle class $(>40<80 \%$ ) as a rule declined subsequent to democratization, while the rich registered significant sharegains. 
The fact that democratization tends to give rise to higher levels of inequality is at first glance counter-intuitive, especially in view of the well-established significant negative correlation between democracy/democratization and inequality: the crosscountry Pearson correlation between level of democracy (Polity2) and the EHII Gini in our sample is -.340, and that between democratization (DEMDUM) and the EHII Gini .364. In both cases the correlations are statistically significant at the 0.01 level, but they probably tell us no more than that countries with lower levels of inequality tend to be more democratic than those that are more unequal, and that positive regime transition is considerably less frequent in countries with high levels of inequality, as Boix (2003) and Acemoglu and Robinson (2006) have shown. What we are interested in, though, is the reverse casual arrow: not how inequality affects democracy, but how democratization affects inequality. By lagging the explanatory variables, and by using a fixed-effects model, we get a better handle on this reverse causal arrow than correlation analysis will allow us to do.

The results of the random-effects estimation in Model 2, however, place the finding of Model 1 in a better perspective. A random-effects model uses the available panel data more efficiently than the fixed-effects estimation, and allows us to draw conclusions also about variable variation across countries. The significant negative coefficient associated with GNIpc underlines that once we distinguish between level of per capita income between countries, the inequality-increasing effect of democratization is no longer statistically significant. If we take into consideration that the events of positive regime change within countries during the period that we are looking at (19601999) were restricted predominantly to LMICs, the findings suggest that there is a distinct dynamic at work in countries with lower per capita income levels which 
determines that democratization does not have the same equality-enhancing effect there as it has/had as a rule in higher-income countries. What is this dynamic?

\section{Explaining the effects of democratization}

The question to be answered in this section is what are the conditions under which democratization in LMICs can (or cannot) mitigate income inequality? Empirically, this way of putting the question implies that we have to get clarity on the vector of control variables that could affect the regularities identified in Table 1. A too easy answer would be to argue that democracies in LMICs simply have not had enough time to consolidate the popular sovereignty that we postulated as such a central feature of democracy, compared to the long consolidation periods that most high-income democracies have gone through. While regime duration is indeed an important qualitative factor in predicting when democracies will manage to mitigate income inequality and when not, as Muller (1988) has shown, this does not really answer the question about what exactly are the institutional and contextual features that allow durable democracies to achieve their salutary effects. We propose to answer this question by means of an extended a priori examination of the medium voter hypothesis $(\mathrm{MVH}),{ }^{13}$ and then to test this explanation by means of an extension of the models used in Table 1.

\footnotetext{
${ }^{13}$ The MVH is an extremely parsimonious, some would say 'simplistic' model of voting outcomes, and deliberately so. By keeping it parsimonious to the extreme, the MVH allows us to show in a controlled way what we have to add to the basic model to understand in a comparative manner what is actually taking place in 'real' democracies. Although there are clear limits to this way of approaching the study of comparative politics, it has obvious advantages as well, especially when we are confronted with such a complex and over-determined phenomenon such as democracy. It seems more constructive to start with a minimum model and then consider what to add to enable us to understand a phenomenon, rather than to try and grasp the complexity of the phenomenon in one comprehensive swoop. Although the ideas behind the MVH can be traced back to the liberal fears of the $19^{\text {th }}$ century that democracies could be more expropriative than oligarchies (Lee, 2003) it was Downs (1957) and especially Meltzer and Richard (1981) that gave current currency to the MVH. For contemporary discussions, applications, and tests of the MVH see Alesina \& Rodrik (1994), Alesina \& Perotti (1996), Persson \& Tabellini (1994), Evans
} 
At any point in time the gross income (income before tax and before redistributive transfers) of the typical individual is shaped by four factors: firstly, by the factor endowment profile of her society, that is, the total amounts of the various factors of production available in the national unit to which she belongs; secondly, by the share that this individual's household has of the total amount of different factors of production; thirdly, by the relative returns received by the different factors; and fourthly, by the size of her household. The political process of democratization has the potential to affect the inter-household distribution of factors of production through fiscal means. It is likely that those who have been excluded from power before would use their new-found political clout to a) enhance their family's share of the pool of human capital in a society by the extension of state-funded general education; and/or b) to change the ownership of fixed factors such as agricultural land and mineral resources by expropriation and redistribution. In an era of generalised economic openness and under conditions of the scarcity of foreign direct investment capital, b) becomes less attractive and less likely than a).

The MVH asks us to imagine, not unrealistically, that a society is composed of members who are differentiated in terms of their individual share of total income. In high-inequality countries such as the LMICs, the citizenry is rather starkly divided into a rich, powerful elite and a poor mass public who compete with one another. ${ }^{14} \mathrm{We}$ assume further that median income level is less than the mean, which is the case in all 'real existing' societies. The regime is a democracy in which all adult citizens have the vote. The government sets the tax rate and can use the revenue earned to promote

(2004), Mueller (2003), Congleton (2002), Borck (2003), Milanovic (2000), and de Mello \& Tiongson (2003).

${ }^{14}$ The discussion here is based on the very useful summary of the MVH that can be found in an unpublished paper by John Roemer (2001). 
equality of opportunity through, amongst others, universal quality education. Two parties form and compete for the majority of the votes on the basis of a platform that consists of one item only, namely the desired tax rules that will tax all incomes at a common rate and deliver educational opportunities for everyone. We can expect a poorer citizen to vote for the party whose proposed tax rate will maximise her children's educational opportunities. In contrast, the elite power-holders would want to extend educational opportunities only marginally to favour economic growth, but not to the extent that it threatens their knowledge-based power. The MVH states that the tax rate chosen will coincide with the wishes of the voter whose income equals the median income. From a game-theoretic perspective the two competing political parties can reach a unique Nash equilibrium, that is, an outcome where no player can benefit by changing his strategy while the other players keep their strategies unchanged, if both parties propose the preferred tax rate of the median voter. The MVH entails two conclusions. Firstly, and assuming that all else remains equal, the introduction of the popular vote should enable the poor mass (those citizens whose income levels fall below the mean) to improve their income share anything up to the level of equality around the mean. Extending the vote to all adult citizens thus empowers the 'rabble to redistribute', implying that democracy may be more expropriative and therefore more equalising than autocracy. Secondly, we can expect higher levels of inequality to lead to increased incentives on the median voter to favour deeper redistribution, seeing that the higher the level of income inequality the bigger the gap between median and mean (Alesina \& Rodrik, 1994; Persson \& Tabellini, 1994).

Seen from this perspective, what autocracy with its restrictions on who may vote does is, in effect, to censor the distribution of voters on the income ladder, shifting the income position of the influential voter upwards (Rudra \& Haggard, 2005:1018). The 
likely result is that the decisive 'voter' in an autocracy - if voting takes place at all - is not the median income earner whose income, as we said, falls below the mean, but someone with a higher income, and we can thus expect autocracies to be less committed systematically to redistribution. ${ }^{15}$ One reason why episodes of democratization during the second half of the $20^{\text {th }}$ century have not been effective in terms of mitigating income inequality is that these episodes simulated the upward effect that autocracy has on the location of the influential voter. What are the conditions under which this may happen? Shapiro suggests that these conditions may have to do with both the demand and supply-side of redistribution (Shapiro, 2003).

\section{Demand side}

The demand for redistribution is a function of a number of factors. First and foremost, as our discussion of the MVH above illustrates, any censoring that takes place in the range of voters, shifts the income level of the median voter upwards and could thus affect the preferences of the decisive voter. Such censoring is per definition part of autocracy, but it may also occur in a democracy when for whatever reason the median voter cannot effectively articulate her demand. Large differentials in income and wealth could be one of the reasons why some cannot 'afford' to vote, or cannot have their views adequately voiced. If we assume that political influence is a consumption good, then citizens with higher incomes should be able to secure more of it than those lower down the income and wealth ladder (Putterman, 1997; Bassett, Burkett \& Putterman, 1999). A high level of income inequality can thus mean that the median voter is too poor to have the political-demand effect that the MVH suggests. This does not imply

\footnotetext{
${ }^{15}$ This does not mean that autocracies are never redistributive. Authoritarian redistributive populism both of leftist and rightist varieties has been a common occurrence both in Southern Europe, Latin America, South-east Asia, and in parts of Africa. As Wintrobe (1998) has argued, insecure authoritarian leaders also seek legitimacy through redistribution, while communist totalitarianism in East and Central Europe was associated with some of the lowest levels of income inequality that could be found anywhere in the twentieth century.
} 
that popular sovereignty is impossible in highly unequal societies, but the close positive correlation between income level and democracy, and the close negative correlation of both with inequality, suggest that highly unequal relative poor societies face exceptional challenges to institutionalise popular sovereignty. Widespread poverty (and geographic distance) may pose prohibitive costs for the median voter even to turn up at the ballot station. The median (influential) voter can only be found among the voters who turn up at the election booth (Lee \& Roemer, 1998:230 and 238, fn 8; Downs, 1957). If, for whatever reason, the median voter who votes occupies a position higher than the median on the income ladder, then the decisive income earner's effective demand for redistribution will accordingly diminish. As a rule, one would expect this to be less of a factor in a society where the fruits of education are widely spread, as there is a correlation between average levels of education achieved and participation in democratic practices. ${ }^{16}$

Secondly, the MVH's core assumption that the electorate faces only one issue at election time clearly is unrealistic and has to be relaxed (Roemer, 1998). Party platforms presented to voters usually contain a myriad of issues and the median voter's eventual choice is determined by trade-offs amongst these and may depend on which party's package deal of issues is most attractive on balance, for her. This may affect her choice of what should be included in the favoured redistributive package, and how redistributive elements such as universal education, public health services, old-age pensions (to name but a few) should be balanced. However, the degree of redistribution that she demands may also be affected by the public debates that surround the various party platforms between which she must choose. For instance, the preferences of the

\footnotetext{
${ }^{16}$ The relationship between level of education achieved and democracy is more complex than Lipset (1959) assumed. See Acemoglu et al. (2005) for a rebuttal of the view that higher average levels of education leads to democracy. However, within democracies, the more educated a citizen, the more she is likely to become involved in electoral politics.
} 
median voter concerning an ideal tax rate approaching unity may be off-set by what she comes to believe about the likely effect of a particular redistributive strategy on future economic growth and political stability. ${ }^{17}$ One important consideration in this regard is that the voter may have been persuaded that expropriation or the drastic increase of taxes on wealth in a relatively open global economy is a recipe to encourage capital flight, which could have dire consequences for future capital investment and growth prospects. Usually, there is no shortage of voices conveying this message during an era of globalisation and although its proponents are clearly self-serving in how this is presented, it does indicate one of the strategic choices that the median voter has to consider and which may reduce her commitment to an expropriative tax rate. Work done by Boix (2003) and Acemoglu and Robinson (2006) shows that the mobility of capital is an important consideration for elites in highly unequal societies when they have to weigh-up the relative costs of continued repression under autocracy versus the potential costs of redistribution. One explanation for the rush of democratization in many repressive autocracies the latter decades of the $20^{\text {th }}$ century is that the liberal global regime of relaxing capital controls has made elites more inclined to accept democratization, as they can credibly threaten capital flight and hence restrict the redistributive costs under such a regime. As Boix puts it: 'The process of capital liberalization (in a politically fragmented world) fosters the exit option of asset holders that speeds up the introduction of democracy' (Boix, 2003:240). The reverse also holds, we would suggest: the process of capital liberalization undermines the bargaining power of the median voter to effect significant redistribution, as the threat of capital flight holds the process of expropriation to ransom. Looked at from this perspective, the

\footnotetext{
${ }^{17}$ For extensive and very useful overviews of the reasons why the median voter may not necessarily prefer a tax rate of unity, or may not be able to secure it even if she prefers it, see Shapiro (2003: chpt 5), Putterman (1997), Borck (2003), Lee (2003), and Roemer (1998).
} 
degree of capital controls applicable to a political jurisdiction may serve as an

approximate indicator of the relative bargaining power of the median voter. ${ }^{18}$

Finally, the literature also suggests that demographic factors can affect the demand for redistribution. The higher the age of the median voter - which also makes her more likely to vote - and the more likely it is that she will reside in an urban area, the larger her demand for inter-generational redistribution will be (Boix, 2003; Perotti, 1996; Bassett, Burkett \& Putterman, 1999; de Mello \& Tiongson, 2003). In developing LMICs, where provision for the old is less well developed, the elderly are relatively better off in rural areas where they can continue to benefit from small agricultural production and extended families.

Supply side

Apart from conditions which could affect the demand for redistribution, the implementation of redistribution driven by popular sovereignty also depends on the ability and capability of public authorities to live up to the demands of the median voter.

\footnotetext{
${ }^{18}$ Structural features of the economy and specifically of the labour market may influence the median voter's bargaining power, thus affecting the demand for redistribution. If we entertain the plausible assumptions a) that the median income earner is a relatively skilled labourer, and b) that to effectively voice her demand for public redistribution she has to overcome typical collective action problems in developing LMICs. In a series of recent publications, Rudra has shown that the collective action resources of our median voter will be affected crucially by the presence of surplus labour and the ratio of skilled to unskilled labour in a society at any given time (Rudra 2002; 2005; Rudra \& Haggard, 2005). She proposes the notion of 'potential labour power' (PLP) to capture the collective action potential of our median voter. PLP grows as the ratio of skilled to unskilled labour increases, but will decrease with the size of surplus labour, which is measured as the working-age population minus the economically-active population and students in secondary and tertiary education. As we already have an alternative indicator of median voter bargaining power (see below), and since the PLP data is available only for a limited group of countries, I do not explore the effect of PLP any further here.
} 
This means that we have to consider not only the demand-side but also the supply-side of the democracy-redistribution equation. Crucial in this regard is the capacity of the state to collect revenue and to manage effectively redistribution programmes such as a system of public education, basic health provision, social welfare, old-age pensions, and anti-cyclical macro-economic policy measures to offset the effects of economic contractions or external shocks.

Such external shocks were quite prominent during the latter part of the 20th century, precipitated by generalised trade liberalisation that increased income inequality in both high income countries and LMICs. From the standard economic point of view, trade liberalisation if followed by an increase in trade should contribute to equalising incomes in developing societies with an abundance of unskilled labour. The HeckscherOhlin trade model concludes that under conditions of an open trading system countries will tend to export goods intensive in the factors that they have in abundance, while they will import goods that use factors that are relatively scarce. With the easing of trade that generalised openness brings, domestic prices of goods whose production uses scarce factors will tend to fall as imports drive down local prices, while local prices for goods that use abundant factors intensively will rise. Stolper and Samuelson (1941) extended this insight by adding that returns to the holders of factors of production that are intensively used will rise absolutely and disproportionally as prices for those goods rise, while the exact opposite will happen to the holders of scarce factors used in the production of goods whose prices fall. All else being equal, then, unskilled labour which is per definition relatively abundant in developing societies should benefit disproportionally from trade liberalisation and the resulting specialisation in competitive advantage (Ray, 1998: 648-652; Reuveny \& Li 2003: 579). This should lead to an improvement in income inequality because the share of unskilled labour in national 
income increases and because we know that if the ownership of some factor $j$ is more widely distributed than that of factor $k$, say, an increase in the national income share of $j$ will reduce inequality (Andersen, 2005).

These expected inequality-reducing effects of greater openness could be neutralised, however, by a number of conditions. Firstly, a preponderance of natural resources - such as oil - may alter the equation. The ownership of factors such as land, resources, and capital has no 'natural' upper limit, in contrast to human skills, and their potential to increase inequality is therefore unbounded (Spilimbergo et al., 1999: 81). Secondly, once we expand the basic trade model discussed above to include many countries with varying ratios of skilled to unskilled labour, the dynamics can also change. In general, openness in a large $n$ system should raise the relative demand for skilled labour in middle-income developing countries whose supply of skilled relative to unskilled labour is higher than the world average (Anderson, 2005:1047). In addition, the presence in a relative open world system of large producers and exporters of goods which use unskilled labour intensively may reduce the competitive advantage that smaller late-comers may have in unskilled labour, thus altering the demand-structure in favour of more skilled labour in these societies. If skilled labour is relatively scarce, though, this shifting demand will benefit only a few and thus increase overall inequality (Wood, 1997).

The available evidence suggests that low- and lower-middle income developing countries are clearly much more vulnerable to the inequality-increasing effects of economic openness than their richer counterparts. Independent confirmation of this openness-vulnerability thesis is supplied by Milanovic (2002) who finds on the basis of solid evidence gleaned from household surveys that the inequality-increasing effects of 
openness and liberalisation are much more pronounced in the case of low income countries. Dependence on private capital inflows, including FDI, increased significantly since the 1970s, which increased access to technology and encouraged production away from low-tech goods which is relative untradable due to the flooding of world markets by large low-skill producers. This led to an increase in demand for skilled labour which is a factor endowment in relative short supply in these countries, as we have seen, due to the creation of long-term labour institutions that concentrated the ownership of human capital, and due to the relative failure of contemporary governments to disseminate skills more widely. In these countries skills are disseminated only amongst a small segment of the labour force, which means that only a small group can benefit from the larger factor rewards brought about by technological innovation and trade specialisation, with the result that the already high levels of wage differentials increase even further. Low-income countries are particularly vulnerable to these effects (Wood, $1995 ; 1997)$.

That factor underlines the important role that an efficient, honest, and politically independent bureaucracy can play to cushion the potential disturbing effects of economic openness by raising revenue and spending it, amongst others, on disseminating appropriate skills in society through investment in education. The ability to deliver public goods such as universal education and health services is a matter of resource availability, but also of the capacity and efficiency of the public institutions that are tasked to extract revenue and deliver public goods and services. In this context the relative political capacity of the state, approximated by the ratio between the amount of revenue raised and the potential revenue size, may be a good indicator of state efficiency. Lee finds that a one point increase in government tax revenue as a percentage share of GDP decreases the Gini inequality score of an institutionalised 
democracy by up to eight percentage points. In partial democracies and autocracies, on the other hand, a larger public sector size is consistently associated with higher income inequality (Lee, 2005:174).

Test

In summary, then, there are a number of contextual and regime features that in combination with one another play an important part in determining whether democratization in LMICs will over time mitigate the high inequality levels that are common in these countries. We identified three important demand-side control variables that have to be added to our estimation of the effect of democratization on income inequality: a) the average level of education achieved within a society; b) the potential bargaining power of the median voter, approximated by the level of capital controls; and c) the demographic structure of society. On the supply side, a relative politically capable state, approximately indicated by its extractive capacity, seems to be an important redistributive factor under conditions of generalised economic openness. The next step is to see how these control variables fair in an extended version of the models used in Table 1, which is reflected in Models $3 \& 4$ in Table 2 . Note that due to the co-linearity between GNIpc and some of the control variables introduced in these latter models, GNIpc is dropped as a control variable. In view of the common expectation, suggested first by Kuznets $(1955 ; 1963)$ that economic growth may exacerbate inequality, especially in early phases of economic modernization, the lagged value of GDP growth is included instead. ${ }^{19}$

We estimate the effect of democratization (measured as before in Table 1) on the EHII Gini of 81 countries (58 LMICs), but now controlling for:

\footnotetext{
${ }^{19}$ Figures for growth of GDP in purchasing-power-parity values is from the Penn World Tables, Heston, Summers \& Aten (2003).
} 
- $\quad$ Capital mobility, as measured by the Fraser Institute (Gwartney and Lawson, 2004), which uses an index that looks at the access that citizens have to foreign capital markets and foreigners to domestic markets, plus the absence of restrictions on the freedom of citizens to engage in capital market exchange with foreigners. Based on the preceding discussion, we expect the sign of this variable to be positive.

- $\quad$ Relative extractive capacity of a state, as calculated using the regression equation: $\operatorname{Tax} / \mathrm{GDP}=\beta 0+\beta 1($ time $)+\beta 2($ Mining/GDP $)+\beta 3$ $($ Agriculture/GDP) $+\beta 4($ Exports/GDP) + error term (Feng, Kugler, \& Zak, 2000). The sign should be negative.

- Old: The percentage of population who are 65 years and older (from the 2003 World Bank CD-Rom World Development Indicators). The hypothesis is that this variable's sign will be negative.

- $\quad$ Average years of schooling achieved by cohort 25 years and older (Barro \& Lee, 2000). We expect the sign of this variable's coefficient to be negative.

As in Table 1, all independent variables are lagged one time-period. Table 2 reports the results from the fixed-effects and a random-effects estimation using these variables. 
Table 2: Estimations of net effect of democratization on income inequality

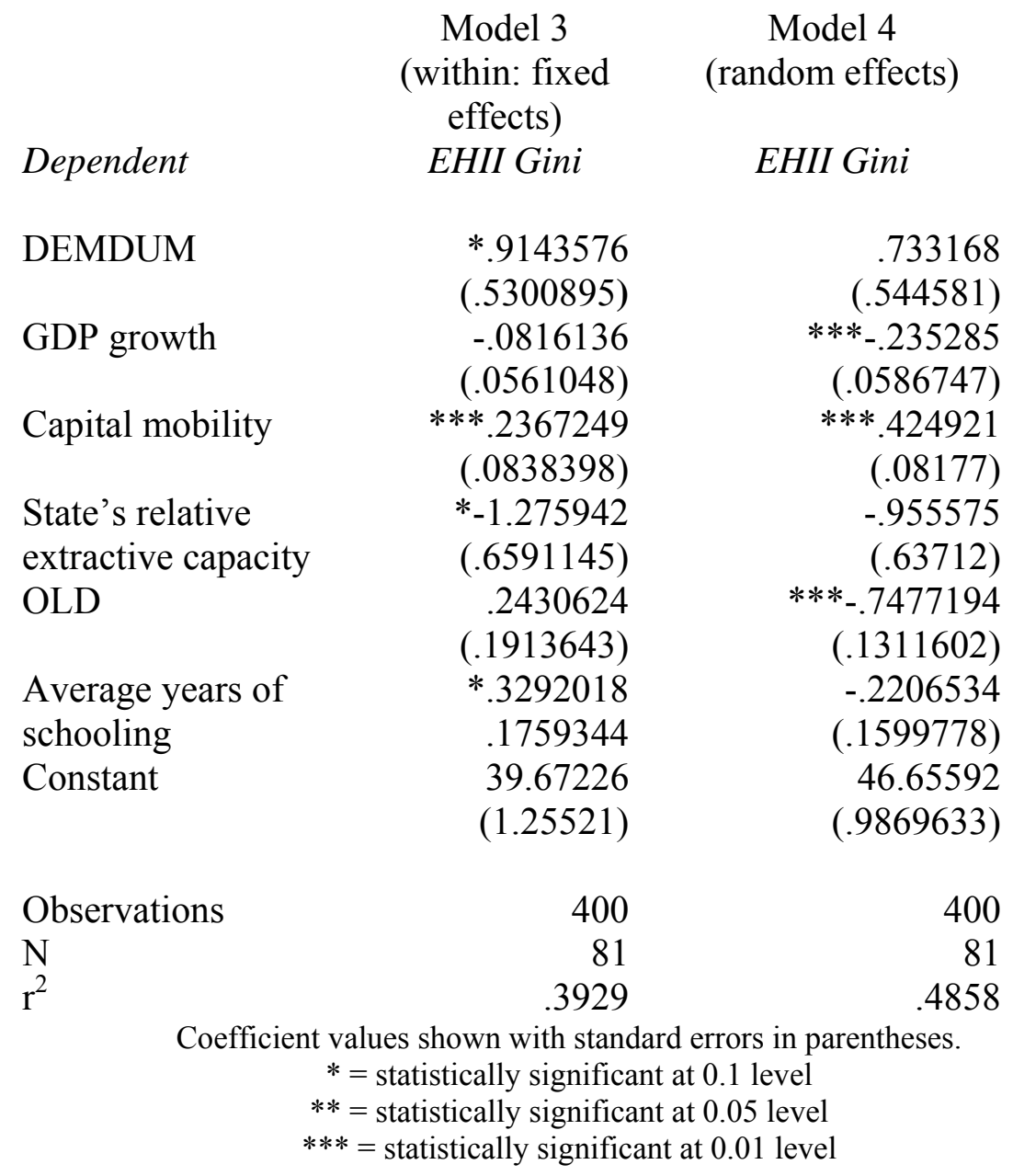

The first noticeable point about Model 3, which is the fixed-effect model, is that the transition to democracy remains statistically significant but less so than in Model 1 (Table 1) now that we control for the effect of the demand and supply-side factors listed above. In the random-effect model (Model 4), this significance - and with it the crosscountry difference between democracies and non-democracies - disappears under the combined effects of these control variables. Five other findings also stand out: firstly, the reduction of capital controls within countries is highly significant and associated with rising subsequent inequality levels, and countries with less capital controls are more unequal than those with more. Models $3 \& 4$ thus strongly confirm the hypothesis that under the credible threat of capital flight it becomes less likely that the electorate 
will use the vote to institute measures that will drastically reshape patterns of income distribution in a country. Secondly, it is only in the within-country context that the growing capacity of the state is significant: as states democratise and the state grows stronger, the amelioration of inequality becomes more likely. However, the effect is not significant across countries. While the sign of the state capacity coefficient is still the expected negative, it does not seem to be such an important factor explaining variation between than within countries.

Thirdly, countries with higher proportions of the elderly in their population clearly have a better track record in dealing with inequality under conditions of institutionalised democracy, as is the case in most high income OECD countries, than do developing countries. As expected, the urban elderly in high income countries are more politically active and capable than their relatively more numerous younger counterparts in LMICs, and articulate the demand for equality-increasing intergenerational transfers quite decisively. What little and insignificant impact the increase of the number of the elderly over time within countries has, tends to worsen inequality.

Fourthly, the results of Models $3 \& 4$ show that economic growth does have the potential to depress inequality, but this effect is not significant either within or between countries. The implications are firstly that there is no credible evidence of a growthinequality trade-off within countries, contrary to the expectations generated by the Kuznets hypothesis, ${ }^{20}$ and secondly, that democracy marginally helps to spread the fruits of faster economic growth somewhat more equitably than partial democracies or autocracies do.

\footnotetext{
${ }^{20}$ For a discussion, see Ray (1998).
} 
Fifthly, and surprisingly, the net effect of the average level of schooling is not significant in the random-effects, but is in the fixed-effects model. The latter shows that overall, when we account for all variation, higher levels of education seems to be associated only weakly with lower inequality. More significantly, rising levels of average schooling achieved within countries may worsen inequality, though. The sign of the coefficient in the fixed-effects model suggests that spreading education within a society does not ipso facto reduce inequality. Instead, before a critical level of the dissemination of skills is achieved, marginal educational advances can exacerbate income differentials between those that receive the higher level of education and those that do not, given the general income premium that there is on skilled labour. In this respect something of a Kuznets effect seems to be still relevant: as economies modernise and the premium on skilled labour increases, those who manage to improve their educational levels compared to the rest of society also draw more benefit in terms of higher relative income. Only when secondary and higher education becomes more universally available will the effect of the skill premium decline.

\section{Conclusions}

This study set out to determine why it is that the spate of positive regime transitions to democracy in LMICs during the latter part of the $20^{\text {th }}$ century has not been accompanied by the reversal of patterns of income inequality. What sets this study apart from other investigations of the relationship between democracy and income distribution are the explicit focus on a dynamic factor, namely democratization, and the utilisation of a 
consistent data source on gross income differentials in a large group of high income countries and LMICs.

There are many factors that can account for the failure of regime transition from autocracy to give rise to greater economic equity in LMICs. As noted earlier, LMICs are composed of ex-communist transition economies on the one hand and so-called developing countries on the other. The literature has suggested specific reasons why inequality has risen during the latter decades of the $20^{\text {th }}$ century in the case of the excommunist transition countries, including China. The primary explanations that have been offered for these trends in the transition economies are, in the case of China, the big divergence between rural and urban wages which resulted from the economic reforms since 1978 (Blecher, 2005), and the effect of the institution regulating population movement (the hukou) which severely inhibits mobility between the rural areas and urban centres (Liu, 2005). In the case of the transition economies of Central and Eastern Europe and Central Asia, a number of factors contributed to the worsening of income inequality, among which were the rapid rise of unemployment as job security was removed in the wake of the capitalist reforms started in the late 1980s; the fall in minimum wage compared to the average wage as wage-setting norms changed in the wake of large-scale privatization; and the rise of the informal sector (Cornia, 2004: 7). To this list we can add the failure of the educational system to help the unemployed to re-school and re-tool; the effect of rapid inflation and macro-economic instability; and the ability of the relatively well-off and politically powerful to capture rent-seeking opportunities at a direct cost to the less influential. Hellman et al., (2003) shows how what they call a 'capture economy' has emerged in many transition countries, where the rapid and unregulated selling-off of state-owned enterprises in the absence of strong regulatory and democratic institutions provided opportunities for public officials and 
politicians to sell rent- and unequal wealth-generating advantages to private firms. There is good reason to believe that the latter factor of state capture by the elite, during and after the transition from autocracy, also plays a major factor in accounting for the fact that partial democracies in the developing world are associated strongly with increasing inequality.

Moving beyond these more specific explanations of why partial democracies cannot redistribute, this chapter focused on the conditions under which poorer voters in institutionalised democracies (in contrast to partial democracies) can effect a mitigation of income inequality. The median-voter hypothesis helps us to theoretically identify the conditions under which democratization could give rise to redistribution, but these conditions have become very circumscribed and scarce in an era of generalised economic openness. We noted that contrary to mainstream theory, economic openness in general tends to increase and not mitigate income inequality in countries where skilled labour is in short supply. Only in those countries with the requisite state capacity to disseminate skills amongst their populace on a broad scale, the electorate can use the vote effectively to reduce the effects of this tendency. However, the demand for drastically enhanced state spending to spread educational opportunities more generally in poorer societies, which will depend on a form of expropriation through progressive taxation, can be suppressed if there is a credible threat of capital flight. Again, economic openness emerges as a threat and not a boon to attempts to lower inequality levels in developing LMICs in particular. As there are many reasons why we should be concerned about high levels of income inequality in the LMICs, as the 2006 World Bank World Development Report makes abundantly clear, these systemic obstacles to growth-enhancing and pro-poor redistribution have to receive more attention. At a minimum, the macro-economic advisers of and in LMICs should reconsider the general 
assumption that economic openness, tout court, is desirable. While there is good reason to believe that trade openness can enhance growth and equity in societies which have achieved a certain level of human capital development, there are also reasons to be careful not to impose liberalisation of the capital account on societies that have not yet achieved the required level of human capital development. The absence of capital controls, we found, makes it less likely that democratization would be followed by a broader dissemination of educational opportunities in these societies.

Finally, the evidence reviewed here also suggests that the promotion of democratization in LMICs, from within and from without, should be treated more circumspectly and discerningly. While positive regime transition to institutionalised democracy holds many potential benefits for societies with autocratic regimes or with partial democracies, it is clearly a mistake to assume that democratization in and of itself is a panacea for all the economic ills. Redistribution, in particular, is a policy outcome that has to be targeted separately and specifically under conditions of economic openness, and will not simply flow automatically from the extension of popular sovereignty.

\section{References}

Acemoglu, D. \& J.A. Robinson (2006) Economic Origins of Dictatorship and Democracy, Cambridge: Cambridge University Press.

Acemoglu, D, S. Johnson, J. Robinson, \& P. Yared (2005) 'From education to democracy?', American Economic Association Papers and Proceedings, Vol. 95, pp. $44-49$ 
Aghion, P. E. C. and C. Garcia-Penalosa (1999) 'Inequality and Economic Growth: The Perspective of the New Growth Theories', Journal of Economic Literature Vol. 37, No. 4, pp. 1615-1660.

Alesina, A. and D. Rodrik (1994) 'Distributive Politics and Economic Growth', Quarterly Journal of Economics Vol. 109, pp. 465-90.

Alesina, A. and R. Perotti (1996) 'Income Distribution, Political Instability and Investment', European Economic Review 81, 5: 1170-1189.

Anderson, E. (2005) 'Openness and inequality in developing countries: a review of theory and recent evidence', World Development, Vol. 33, No. 7, pp.1045-1063.

Banerjee, A. \& E. Duflo 2000 'Inequality and Growth: What Can the Data Say?' NBER Working Paper Series No... 7793, Cambridge, MA: National Bureau of Economic Research.

Barro, R. (1996) 'Democracy and Growth', Journal of Economic Growth 1, 1: 1-27.

Barro, R. (2000) 'Inequality and Growth in a Panel of Countries', Journal of Economic Growth 5, 1: 5-32.

Barro, Robert J. and Jong-Wha Lee, (2000) 'International Data on Educational Attainment: Updates and Implications', Centre for International Development Working Paper No. 42, available at http://www.cid.harvard.edu/ciddata/ciddata.html

Bassett, W.F., J.P Burkett \& L. Putterman (1999) 'Income Distribution, Government Transfers, and the Problem of Unequal Influence', European Journal of Political Economy, Vol. 15, pp. 207-228.

Bearse, P., G. Glomm \& E. Janeba (2000) 'Why Poor Countries Rely Mostly on Redistribution In-kind', Journal of Public Economics, Vol. 75, pp.463-481. 
Beer, L. \& T. Boswell (2002) 'The Resilience of Dependency Effects in Explaining Income Inequality in the Global Economy: A Cross-National Analysis, 19751995', Journal of World Systems Research, Vol. VIII, No. 1: 30-59.

Benabou, R. (1996) ‘Inequality and Growth', Discussion Paper1450, London: Centre for Economic Policy Research.

Birdsall, N. (2001) 'Why Inequality Matters: Some Economic Issues', Ethics and International Affairs, Vol. 15, No. 2, pp. 3-28.

Birdsall, N. \& J. Londono (1997) 'Asset Inequality Matters: An Assessment of the World Bank's Approach to Poverty Reduction', The American Economic eview, Vol. 87, No. 2, pp. 32-37.

Blecher, M. (2005) 'Inequality and capitalism in China”, unpublished report prepared for the American Political Science Association Task Force Conference on Inequality and Difference in Developing Societies, available at http://www.apsanet.org/content_13916.cfm

Boix, C. (2003) Democracy and Redistribution, Cambridge University Press, Cambridge.

Bollen, K.A. \& R.W. Jackman (1985) 'Political Democracy and the Size Distribution of Income', American Sociological Review, Vol. 50, pp. 438-457.

Borck, R. (2003) 'Voting, Inequality, and Redistribution', DIW Working Paper, July.

http://www.polecon.de/Redistribution.pdf

Burkhart, R.E. (1997) 'Comparative Democracy and Income Distribution: Shape and Direction of the Causal Arrow', Journal of Politics, Vol. 59, No. 1, pp. 149-164. 
Castro-Leal, F., J. Dayton., L. Demery, \& K. Mehra (1999) 'Public Social Spending in Africa: Do the Poor Benefit?' World Bank Research Observer 14, 1: 49-72.

Champernowne, D. \& F. Cowell (1998) Economic Inequality and Income Distribution. Cambridge: Cambridge University Press.

Chan, S. (1997) 'Democracy and Inequality: Tracking Welfare Spending in Singapore, Taiwan, and South Korea', in M. Midlarsky (ed.) Inequality, Democracy, and Economic Development, Cambridge University Press, Cambridge, pp. 227-243.

Chen, S. \& M. Ravallion (2000) 'How did the world's poorest fare in the 1990s?' World Bank Policy Research Working Paper No. 2409, August, available at: http://www.worldbank.org/research/povmonitor/method.htm

Congleton, R. (2002) 'The Median -Voter Model', Contribution prepared for the Encyclopedia of Public Choice. Available at http://rdc1.net/forthcoming/medianvt.pdf

Cornia, G. (ed.) (2004) Inequality, Growth, and Poverty in an Era of Liberalization and Globalization, Oxford: Oxford University Press, 2004.

Dagdeviren, H., R. van der Hoeven. \& J. Weeks 2001 'Redistribution Matters: Growth for Poverty Reduction', ILO Employment Paper 2001/10, Geneva: Employment Sector, International Labour Office.

de Ferranti, D. et al. (2003) Inequality in Latin America and the Caribbean: Breaking with History? World Bank Latin American and Caribbean Studies, Advanced Conference Edition. Available at http://www.cefe.net/forum/Inequality.pdf 
de Mello, L. \& E.R. Tiongson (2003) 'Income Inequality and Redistributive Government Spending', IMF Working Paper WP/03/14. Available from http://www.imf.org/external/pubs/ft/wp/2003/wp0314.pdf

Deininger, K. and L. Squire (1996) ‘Measuring Income Inequality: A New Data Base’, World Bank Economic Review 10, 3: 565-591.

Deininger, K. and L. Squire (1998) 'New Ways of Looking at Old Issues: Inequality and Growth', Journal of Development Economics 57: 259-287.

Diamond, L. (1999) Developing Democracy: Towards Consolidation, Johns Hopkins Press, Baltimore.

Doorenspleet, R. (2000) 'Reassessing the Three Waves of Democratization', World Politics, Vol. 52, pp. 384-406.

Downs, A. (1957) An Economic Theory of Democracy, Harper and Row, New York.

Easterly, W. (2002) 'Inequality does Cause Underdevelopment: New Evidence', Center for Global Development Working Paper No. 1, June. Available at http://www.cgdev.org/wp/cgd_wp001_rev.pdf

Epstein, L., R Bates, J. Goldstone, I Kristensen \& S O’Halloran (2003) ‘Democratic Transitions', Unpublished paper, available at http://www.cid.harvard.edu/cidpeople/bates/Transitions.pdf

Evans, J.A.J. (2004) Voters \& Voting: An Introduction, Sage, London.

Fan, S. \& N. Rao (2003) 'Public Spending in Developing Countries: Trends, Determination, and Impact', Environment and Production Technology Division Discussion Paper No. 99, International Food Policy Research Institute, Washington, DC. Available at http://www.ifpri.org/divs/eptd/dp/papers/eptdp99.pdf 
Feng, Y., Y. Kugler \& P.J. Zak (2000) 'The politics of fertility and economic development', International Studies Quarterly, Vol 44, No 1, pp. 667-693

Galbraith, J.K. \& H. Kum (2005) 'Estimating the inequality of household income: a statistical approach to the creation of a dense and consistent data set', Review of Income and Wealth, Series 51, No. 1, pp. 115-143.

Gradstein, M., B. Milanovic \& Y. Ying (2001) 'Democracy and Income Inequality: An Empirical Analysis', World Bank Research Department. Available at http://www.worldbank.org/research/inequality/inequalityandpolitics/dem,ineq.pdf

Gugerty, M. K. \& C.P. Timmer (1999) 'Growth, Inequality, and Poverty Alleviation: Implications for Development Assistance', Consulting Assistance on Economic Reform II Discussion Paper No. 50, Harvard Institute for International Development, December. Available at http://www.cid.harvard.edu/caer2/htm/content/papers/confpubs/paper50/paper50. $\underline{\mathrm{pdf}}$

Gwartney, J. \& R. Lawson (2004). Economic Freedom of the World: 2004 Annual Report. Vancouver: The Fraser Institute. Data retrieved from http://www.freetheworld.com

Hellman, J., G. Jones, \& D. Kaufmann (2003) 'Seize the state, seize the day: state capture and influence in transition economies', Journal of Comparative Economies, Vol. 31, pp. 751-773

Heston, A., R. Summers \& B. Aten (2003) 'Penn World Table Version 6.1', Center for International Comparisons at the University of Pennsylvania (CICUP). Available at http://datacentre2.cass.utoronto.ca/pwt/docs/pwt61.html 
Justino, P. J. Litchfield \& L. Whitehead (2003) 'The Impact of Inequality in Latin America', Poverty Research Unit at Sussex Working Paper No.. 21. Available at http://www.sussex.ac.uk/Users/PRU

Kanbur, R. (2000) 'Income Distribution and Development', in A. Atkinson \& F. Bourguignon eds. Handbook on Income Distribution. Amsterdam: North-Holland, $791-841$.

Kentor, J. (2001) 'The Long-term Effects of Globalization on Income Inequality, Population Growth, and Economic Development', Social Problems 48, 4: 435455.

Knowles, S. 'Inequality and economic growth: the empirical relationship reconsidered in the light of comparable data', Journal of Development Studies, Vol. 41, 2005, pp. 135-159.

Kuznets, S. (1955) ‘Economic Growth and Income Inequality’, American Economic Review 45: 1-48.

Kuznets, S. (1963) 'Quantitative aspects of the economic growth of nations: VIII. Distribution of income by size', Economic Development \& Cultural Change, Vol. 11, No. 2, Part 2, pp. 1-80.

Landa, D. \& E. Kapstein (2001) 'Inequality, Growth, and Democracy’ (review article), World Politics, Vol. 53, pp. 264-296.

Lane, J. \& S. Ersson (2003) Democracy: A Comparative Approach, Routledge, London.

Lee, C-S. (2005) 'Income inequality, democracy, and public sector size', American Sociological Review, Vol. 70, No. 1, p. 158.

Lee, W. (2003) 'Is Democracy more Expropriative than Dictatorship? Tocquevillian Wisdom Revisited', Journal of Development Economics, Vol. 71, pp. 155-198. 
Lee, W. \& J.E. Roemer (1998) 'Income Distribution, Redistributive Politics, and Economic Growth', Journal of Economic Growth, Vol. 3, pp. 217-240.

Lipset, Seymour M. (1959) 'Some social requisites of democracy: economic development and political legitimacy', American Political Science Review, Vol. 53, pp. 69-105.

Liu, Z. (2005) 'Institution and inequality: the hukou system in China', Journal of Comparative Economics, Vol. 33, pp. 133-157.

Marshall, M. \& K. Jaggers (2000) 'Polity IV Project: Political Regime Characteristics and Transitions, 1800-1999', Center for International Development and Conflict Management, University of Maryland, available at http:www.bsos.umd.edu/cidcm/inscr/polity

Marshall, M. and K. Jaggers (2002) POLITY IV PROJECT, Political Regime Characteristics and Transitions, 1980-2002, Dataset Users' manual.

Meltzer, A.H. \& S.F. Richard (1981) 'A Rational Theory of the Size of Government', The Journal of Political Economy, Vol. 89, No.. 5, pp. 914-927.

Milanovic, B. (2000) 'The Median-voter Hypothesis, Income Inequality, and Income Redistribution: an Empirical Test with the Required Data', European Journal of Political Economy, Vol. 16, pp. 367-410.

Milanovic, B (2002) "Can we discern the effect of globalisation on income distribution? Evidence from household budget surveys" World Bank Policy Research working paper 2876, April.

Muller, E. N. (1988) 'Democracy, Economic Development, and Income Inequality', American Sociological Review, Vol. 53, pp. 50-68.

Mueller, D.C. (2003) Public Choice III, Cambridge University Press, Cambridge. 
Naschold, F. (2002) 'Why inequality matters for poverty’, Inequality Briefing Paper No.

2, UK Department for International Development, March.

Nel, P. (2003) 'Income inequality, economic growth, and political instability in subSaharan Africa', Journal of Modern African Studies, Vol. 41, No. 4, pp. 611-639.

Nel, P. (2005) 'Democratisation and the Dynamics of Income Distribution in Low and Middle-income Countries', Politikon, Vol. 32, No. 1, pp. 17-43.

Nelson, P. (1999) 'Redistribution and the Income of the Median Voter', Public Choice, Vol. 98, pp. 187-194.

Perotti, R. (1996) 'Growth, Income Distribution, and Democracy: What the Data Say', Journal of Economic Growth 1, 2: 149-188.

Persson, T. \& G. Tabellini (1994) 'Is Inequality Harmful for Growth?’ American Economic Review 84, 3: 600-621.

Przeworski, A., M. Alvarez, J. Cheibub \& F. Limongi (2000) Democracy and Development: Political Institutions and Well-Being in the World, 1950-1990. Cambridge: Cambridge University Press.

Putterman, L. (1997) 'Why have the Rabble not Redistributed the Wealth? On the Stability of Democracy and Unequal Property', in J.E. Roemer (ed.) Property Relations, Incentives, and Welfare, Macmillan, London, pp. 359-389

Ray, D. (1998) Development Economics. Princeton: Princeton University Press.

Reich, G. (2002) 'Categorizing Political Regimes: New Data for Old Problems”, Democratization, Vol. 19, No. 4, pp. 1-24.

Reuveny, R. \& Li, Q. (2003) 'Economic Openness, Democracy and Income Inequality: An Empirical Analysis', Comparative Political Studies, Vol. 36, No. 5, pp. 575601. 
Robinson, W. (1996) Promoting Polyarchy: Globalization, US Intervention ad Hegemony, Cambridge University Press, Cambridge.

Rodrik, D. (1999) The New Global Economy and Developing Countries: Making Openness Work, Overseas Development Council and the Johns Hopkins Press, Washington DC.

Roemer, J. (1998) 'Why the Poor do not Expropriate the Rich: an Old Argument in New Garb', Journal of Public Economics, Vol. 70, pp. 399-424.

Roemer, J. (2001) 'Democracy, educational finance, and the distribution of human capital: a dynamic analysis'. Unpublished paper, available at http://mora.rente.nhh.no/projects/EqualityExchange/Portals/0/articles/roemer3.pdf

Rudra, N. (2002) 'Globalization and the Decline of the Welfare State in Less-developed Countries', International Organization 56, 2: 411-445.

Rudra, N. (2005) 'Globalization and the strengthening of democracy in the developing world', American Journal of Political Science, Vol. 49, No. 4, October, pp. 704730.

Rudra, N. \& S. Haggard (2005) 'Globalization, democracy, and effective welfare spending in the developing world', Comparative Political Studies, Vol. 38, No. 9, pp. $1015-1049$.

Rueschemeyer, D., E.H. Stephens \& J.D. Stephens (1992) Capitalist Development and Democracy, University of Chicago Press, Chicago.

Sanders, D. (1981) Patterns of Political Instability, St Martin's Press, New York. Shapiro, I. (2003) The State of Democratic Theory, Princeton: Princeton University Press. 
Simpson, M. (1990) 'Political Rights and Income Inequality: a Cross-national Test', American Sociological Review, Vol. 55, pp. 682-693.

Spilimbergo, A., J.1. Londono, \& M. Szekely (1999) "Income distribution, factor endowments, and trade openness", Journal of Development Economics, Vol. 59, pp. $77-101$.

Stolper, W. \& P. Samuelson (1941). "Protection and Real Wages", Review of Economic Studies, 9: 58-73

Vanhanen T. (2003) Democratizaion: A Comparative Analysis of 170 Countries, Routledge, London.

Verdier, T, \& A. Ades (1996) 'The Rise and Fall of Elites: A Theory of Economic Development and Social Polarization in Rent-seeking Societies', London: Centre for Economic Policy Research, Discussion Papers No. 1495.

Wood, A. (1995) 'How trade hurts unskilled workers', The Journal of Economic Perspectives, Vol.9, No. 3, pp.57-80.

Wood, A. (1997) "Openness and wage inequality in developing countries: the Latin American challenge to East Asian conventional wisdom", The World Bank Economic Review, Vol. 11, pp.33-57.

Wintrobe, D. (1998) The Political Economy of Dictatorship, Cambridge: Cambridge University Press.

World Bank (2001) Attacking Poverty - World Development Report 2000-2001. Washington, DC: The World Bank.

World Bank (2003) World Development Indicators, CD-Rom. Washington, DC: World Bank. 
World Bank (2005) Equity and Development: World development Report 2005/2006.

Washington, DC: The World Bank. 